\title{
Water Use and Crop Coefficients of Woody Ornamentals in Containers
}

\author{
Ursula K. Schuch \\ Department of Botany and Plant Sciences, University of California, Riverside, CA 92521 \\ David W. Burger \\ Department of Environmental Horticulture, University of California, Davis, CA 95616
}

AdDITIONAL INDEX words. irrigation management, nursery production, atmometer, $\mathrm{ET}_{\text {gage, }}$ reference evapotranspiration, ET

\begin{abstract}
Twelve species of woody ornamentals were grown in containers in Riverside and Davis, Calif., to determine plant water use and compare crop coefficients $\left(K_{c}\right)$ calculated with reference evapotranspiration (ET) from local weather stations $\left(E T_{\text {cim }}\right)$ or atmometers $\left(E T_{a t m}\right)$. Water use, $K_{\mathbf{c}_{a t m}}$, and $K_{\mathbf{c}_{\text {cim }}}$ differed by species, location, and month of the year. Raphiolepis indica (L.) Lindl., Pittosporum tobira (Thunb.) Ait., Juniperus sabina L., and Photinia $\times$ fraseri Dress. were the highest water users in Riverside and Arctostaphylos densiflora M.S. Bak., Juniperus, Cercis occidentalis Torr., and Pittosporum used the highest amount of water in Davis, when averaged over the 20 -month study period. Rhamnus californica Eschsch., Prunus ilicifolia (Nutt.) Walp., and Cercocarpus minutiflorus Abrams. were among the lowest water users in both locations. Although plant water use fluctuated considerably between individual sampling dates, the relative ranking of species water use in each location changed very little over the study period. During periods of high winds, $\mathbf{E T}_{\text {cim }}$ may not provide an accurate reference for container crops. $K_{c}$ values fluctuated seasonally from as much as 1 to 4.7 for high water users, while values were stable for low water users and also for Buxus microphylla japonica Rehd. \& E.H. Wils., an intermediate water user. During periods of low ET, especially in fall and winter, $K_{c}$ values were artificially high and failed to correspond to the plants' low water use. $K_{c}$ values for low water users seem to be useful to estimate water requirements over an extended period of time, whereas general $K_{c}$ values seem to have limited value for plants with high water demand and need to be modified for different growth stages and growing locations.
\end{abstract}

Water use requirements of ornamental nursery crops are of greater interest as nurseries attempt to conserve water and reduce runoff. Increasing water prices, possible allocation or availability limits, and pollution of groundwater and surface water through runoff are rationales to estimate the amount of water plants need as closely as possible. Once daily water use requirements are known, irrigation efficiency can be increased by grouping plants with similar irrigation demands.

Water use of plants is a function of evaporation and transpiration and, therefore, fluctuates considerably daily. In addition to climatic factors, evapotranspiration of a specific crop will be influenced by plant morphology and physiology of the individual plant, as well as the characteristics of the crop canopy (Doorenbos and Pruitt, 1975). Evapotranspiration is calculated or estimated from meteorological data. To relate the effect of different climatic conditions on growth characteristics of a crop, reference crop evaporation (ET) has been defined as the rate of evapotranspiration from an extensive surface of 8 to $15-\mathrm{cm}$-tall green grass cover of uniform height, actively growing, completely shading the ground, and not short of water (Doorenbos and Pruitt, 1975). Crop coefficients $\left(\mathbf{K}_{\mathfrak{c}}\right)$ were then developed to compare water use of a specific crop to that of a reference crop (Doorenbos and Pruitt, 1975). Dimensionless $\mathbf{K}_{\mathfrak{c}}$ values are calculated as follows:

$\mathrm{K}_{\mathrm{c}}=\mathrm{ET}_{\text {crop }} / \mathrm{ET}$

$\mathrm{ET}_{\text {crop }}$ is measured over the course of a day, week, or month. ET can be obtained by collecting meteorological data and calculating daily, weekly, or monthly ET with the Penman (1948), radiation (Makkink, 1957), or Blaney-Criddle equation (1950), or using

Received for publication 12 July 1996. Accepted for publication 27 May 1997. We gratefully acknowledge the technical assistance of D. Holt and G. Forrister and financial support from the California Association of Nurserymen and the Elvinia Slosson Foundation. The cost of publishing this paper was defrayed in part by the payment of page charges. Under postal regulations, this paper therefore must be hereby marked advertisement solely to indicate this fact. direct methods such as pan evaporation (Doorenbos and Pruitt, 1975). In California, the California Irrigation Management Information System (CIMIS) weather stations collect data in different locations throughout the state and calculate ET with the modified Penman equation. While this data is of great interest for a general geographic area, it may not account for local microclimates.

Atmometers are alternative devices that estimate evapotranspiration by exposing porous ceramic or paper evaporating surfaces to the atmosphere (Doorenbos, 1976; Rosenberg et al., 1983). Atmometers need to be calibrated to actual ET data, as they are sensitive to placement and exposure. According to the manufacturer, cumulative ET measured with an atmometer, as the one used in this study, is very similar to ET as calculated from the Penman-Monteith, turf-based equation (C. Asbell, personal communication).

For container crops, $\mathrm{K}_{\mathrm{c}}$ has been calculated to account for the surface area of the container where water enters the soil volume (Burger et al., 1987).

$\mathrm{ET}_{\text {crop }}=$ crop water use/container surface area

where $\mathrm{ET}_{\text {crop }}$ is in centimeters, crop water use is in cubic centimeters, and container surface is in square centimeters. $\mathrm{K}_{\mathrm{c}}$ for container crops is then calculated according to Eq. [1].

Crop coefficients were first developed for agronomic or orchard crops with a uniform canopy such as alfalfa (Medicago sativa L.) pastures, citrus (Citrus sp.), apples (Malus domestica Borkh.), and peaches (Prunus persica L. Batsch.) (Doorenbos and Pruitt, 1975). Coefficients for individual crops change with the rate of crop development, the length of the growing season, and cultural practices (Doorenbos and Pruitt, 1975; Regan, 1994). Crop coefficients for containerized woody ornamental plants ranging from $<1$ to $>5$ have been reported (Burger et al., 1987; Regan, 1994). Many of these $\mathbf{K}_{\mathfrak{c}}$ values are considerably higher than those reported for field crops, which rarely exceed 1.3 (Doorenbos and Pruitt, 1975). Plants growing in containers seem to have more similarities to isolated stands of vegetation than to a uniform crop 
canopy. Isolated or nonuniform vegetation has a greater $\mathrm{K}_{\mathrm{c}}$ value than large, continuous areas of plant cover because single plants capture more net radiation and have a higher resistance to heat flux (Allen, 1993). Isolated plants are subject to advection and higher $\mathrm{Et}_{\mathrm{crop}}$ and, therefore, higher $\mathrm{K}_{\mathrm{c}}$ can be expected for these plants or at the edge of small plots (Doorenbos and Pruitt, 1975).

Changes in the $K_{c}$ of field crops are often proportional to canopy coverage, for example, in tomato (Lycopersicon esculentum Mill.) The $\mathrm{K}_{\mathrm{c}}$ value is 0.2 during the establishment phase and increases to 1.1 for the fully developed canopy (Snyder et al., 1987). Higher $\mathrm{K}_{\mathrm{c}}$ values for container crops are due to the difference between the container surface area and the variable surface area of the plant canopy (Burger et al., 1987). In container crops it is not unusual for the canopy to considerably exceed the container surface area. For a large plant in a small container, high crop water use will result in a higher $\mathrm{K}_{\mathrm{c}}$. If that same plant were transplanted to a larger container with increased surface area and water use and ET remained the same, $\mathrm{ET}_{\text {crop }}$ would be lower and subsequently $\mathrm{K}_{\mathrm{c}}$ would be lower.

The objectives of this study were to 1) determine the water use of 12 containerized woody ornamental plant species growing in two locations in California from the liner stage up to 2 years and 2) compare $K_{c}$ values as determined with ET data from CIMIS or atmometers.

\section{Materials and Methods}

The following plant species were used in this study: Arctostaphylos densiflora M.S. Bak. 'Howard McMinn', Buxus microphylla japonica Rehd. \& E.H. Wils. 'Green Beauty', Ceanothus sp. L. 'Concha', Cercocarpus minutiflorus Abrams., Cercis occidentalis Torr., Heteromeles arbutifolia (Ait.) M.J. Roem., Juniperus sabina L. 'Buffalo', Photinia $\times$ fraseri Dress., Pittosporum tobira (Thunb.) Ait., 'Wheelers Dwarf', Prunus ilicifolia (Nutt.) Walp., Raphiolepis indica (L.) Lindl. 'Springtime', and Rhamnus californica Eschsch. 'Eve Case'. Liners were transplanted in August 1992 into 3.0-L black polyethylene containers with Univ. of California no. $3 \mathrm{mix}$ (Baker, 1985) and established outdoors. In Davis, plants were irrigated to saturation with overhead sprinklers once a week from November to March and every other day from March to November. In Riverside, overhead irrigation was applied to saturation once a day from July to October, and two to three times a week for the rest of the year. In Riverside, controlled-release fertilizer (20N-7P-10K, Nutricote, Brampton, Ontario) was added as topdress at transplanting and was replenished at $\approx 4$-month intervals at $5 \mathrm{~g} /$ pot for Photinia, Pittosporum, Buxus, Raphiolepis, and Juniperus, and at $2.5 \mathrm{~g} / \mathrm{pot}$ for the remaining seven species. In Davis, the same fertilizer as described above was applied at $15 \mathrm{~g}$ per pot at transplanting, and follow-up applications were made in spring of the following years. Plants were moved to 15.6-L containers in Spring 1994, 19 months after transplanting. Containers were spaced can tight immediately after transplanting. A closed canopy, similar to nursery production conditions, was maintained, as containers were gradually spaced further apart to allow for horizontal canopy expansion. Plants were not pruned in either location during the entire study.

Thirty-two plants of each species were arranged in two blocks of four by four. Water use and plant growth of the central four plants per block was monitored. Using only center plants minimized edge effects of border plants, where one side of the container and plant is exposed to higher solar radiation, generally resulting in slower plant growth. The study was conducted at the Univ. of California at Riverside $\left(33^{\circ} 57 \mathrm{~N}, 117^{\circ} 20^{\mathrm{W}}\right)$ and at Davis $\left(38^{\circ} 32 \mathrm{~N}, 121^{\circ} 46 \mathrm{~W}\right)$.
From March 1993 until November 1994, water use was measured seven and eleven times in Davis and Riverside, respectively, using the following procedure. In the morning, pots were irrigated to saturation, allowed to drain for 1 to $2 \mathrm{~h}$ and then weighed to a resolution of $1 \mathrm{~g}$. Pots were weighed again $24 \mathrm{~h}$ later and the whole procedure was repeated. This provided data of plant water use for two consecutive 24 -h periods during each sample month.

ET during this time was estimated from nearby CIMIS weather stations $\left(\mathrm{ET}_{\mathrm{cim}}\right)$ and from one atmometer $\left(\mathrm{ET}_{\mathrm{atm}}\right)$ (C\&M Meteorological Supply, Colorado Springs, Colo.) installed at canopy height adjacent to each study site. The atmometer $\left(E_{\text {gage }}\right)$ used in this study consists of a ceramic plate covered with a green fabric cover. The bottom of the plate is connected through a rubber stopper with a glass supply tube and a check valve at the lower end of the glass tube. The atmometer plate with the attached glass tube is placed to seal the top of a distilled water reservoir. A water level on the side of the container indicates the amount of water, in millimeters or inches, that is lost through evaporation. The device can be mounted on a pole next to a crop to determine reference evapotranspiration. Two crop coefficients were calculated: $K_{c_{c i m}}$, which used the local $\mathrm{ET}_{\mathrm{cim}}$, and $\mathrm{K}_{\mathrm{catm}}$, which used the local $\mathrm{ET}_{\mathrm{atm}}$ in place of ET in Eq. [1]. Plant height and canopy width were frequently measured and canopy size was calculated as the average of height and two widths.

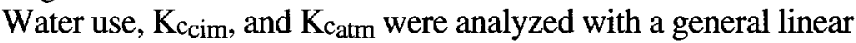
procedure (SAS Institute, Cary, N.C.) including species, locations, and month of the year. Water use at the Riverside location was also calculated as a function of plant height and month of the year. To account for the differences in plant growth throughout the year, the variable month for each year was converted to angles as a fraction of $360^{\circ}$ and the cosine and sine of the angles were used in the regression along with their interactions with plant height. This conversion of month per year to a Fourier curve accounts for fluctuations that occur at regular intervals (Little and Hills, 1978) and are typical for the seasonal fluctuations encountered in an annual growth cycle.

\section{Results and Discussion}

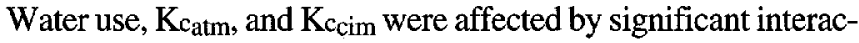
tions between species, location, and month (Table 1, Fig. 1). Water use was primarily influenced by month, while the most important factor for $\mathrm{K}_{\mathrm{c} a \mathrm{~atm}}$ and $\mathrm{K}_{\mathrm{cim}}$ was location. Raphiolepis and Pittosporum, followed by Juniperus and Photinia, respectively were the highest water users in Riverside when averaged over the 20-month study period (Table 2). Arctostaphylos was the highest water user in Davis, followed by Juniperus, Cercis, and Pittosporum (Table2). Rhamnus, Prunus, and Cercocarpus were among the lowest water users in both locations. The largest difference in species water use between the two locations was found for Arctostaphylos and Cercis, both high water users in Davis but moderate or low water users in Riverside. The other species ranked similarly in both locations. Although plant water use fluctuated considerably between individual sampling dates, the relative ranking of species" water use in each location changed very little over the study period.

June and August 1994 were the two sampling times with the highest water use in Riverside and Davis (Table 3). Major climatic differences between the two locations occurred from the middle of June 1993 until the end of August 1993 and June 1994 until the end of July 1994 when $\mathrm{ET}_{\text {cim }}$ in Davis was considerably higher, mainly due to higher solar radiation and greater wind speed (Fig. 2). $\mathrm{ET}_{\text {cim }}$ was higher in Riverside than Davis from the middle of November 1993 until the middle of February 1994 with higher solar radiation. Wind speed at Davis was always higher than at Riverside, with a 
few exceptions during the winter months.

Predicting water use of plants growing in Riverside in response to $\mathrm{ET}_{\mathrm{cim}}$, month of the year, and plant height yielded regressions accounting for $76 \%$ to $94 \%$ of the variation (Table 4).

$\mathrm{ET}_{\text {cim }}$ was generally the most important factor in predicting water use and was added to the model as the first variable following the intercept in the stepwise regression using forward selection. Exceptions were Ceanothus, where the interaction between $\mathrm{ET}_{\text {cim }}$ and sine (month of the year) was most significant, and Pittosporum, where the height squared contributed most to water use. Calculations to predict water use only with plant height, time, and their interactions yielded regressions with poorer $R^{2}$. An attempt to predict $K_{\mathcal{c}}$ with the same variables was even less meaningful.

$\mathrm{ET}_{\mathrm{cim}}$ is the main factor determining water use. The significant interaction between $\mathrm{ET}_{\mathrm{cim}}$ and month of the year indicates that the relationship between water use and reference ET varies seasonally (Table 4). This proportional change of water use in relation to ET was also indicated by the different ranking of months for water use and associated $K_{c}$ values (Table 3).

Crop coefficients $\mathrm{K}_{\mathrm{catm}}$ and $\mathrm{K}_{\mathrm{ccim}}$ of individual species, when averaged over the 20 -month sampling period ranked similar to water use (Table 2). The $\mathrm{K}_{\mathrm{c}_{\mathrm{atm}}}$ and $\mathbf{K}_{\mathrm{c}_{\mathrm{cim}}}$ values of individual species varied considerably between months and years in both locations (Fig. 1). Generally, greater variability was found in 1993 than 1994. Large seasonal fluctuations in $\mathrm{K}_{\mathrm{c}}$ values were found for the high water users (Fig. 1), and values were relatively stable in both locations over the 20 months for low water users such as Cercocarpus and Prunus, but also for Buxus, an intermediate water user.

Raphiolepis and Pittosporum had the largest range of $\mathrm{K}_{\mathrm{c}}$ values in Riverside, ranging from $<1$ to 4.7 (Fig. 1), a range similar to previous studies (Burger et al., 1987; Regan, 1994). Extremely high $\mathrm{K}_{\mathrm{c}}$ values were determined in November and December. While this can be observed to a lesser degree in some of the other species, it seems excessive in Pittosporum and Raphiolepis. The high water users in Davis-Arctostaphylos, Juniperus, Cercis, Pittosporum, and Photinia-also showed the greatest variability in $\mathrm{K}_{\mathrm{c}}$ values ranging from 1 to 4 (Fig. 1).

During 1993, most species had a low $\mathrm{K}_{\mathrm{c}}$ in March and April, a high $\mathrm{K}_{\mathfrak{c}}$ in June and September, and a low $\mathrm{K}_{\mathrm{c}}$ again in October. This pattern is similar in both locations and is easily observed for high water users, but becomes less obvious for species with lower water use. $K_{\mathfrak{c}}$ values differed less in 1994 and were lower than in 1993 when determined during the same month. Exceptions were $\mathrm{K}_{\mathrm{c}}$ values in June for Pittosporum, Juniperus, and Arctostaphylos growing in Davis (Fig. 1). The lower variability in 1994 stems most likely from the plants' being shifted to larger containers in Spring 1994 , thereby increasing the surface area that is used to calculate $\mathrm{ET}_{\text {crop }}$ (Eq. [2]), and thereby lowering $\mathrm{K}_{\mathrm{c}}$.
Dividing plant water use by the surface area of the container is an attempt to normalize crop water use to a uniform surface area, similar to field crops. However, this is an artificial value that is often not correlated to the area that is covered by the canopy. Although the canopy of a 1-year-old plant will initially be smaller than the container surface area and after 1 year will exceed this surface area considerably, no allowances are made for this change in canopy in the $\mathbf{K}_{\mathbf{c}}$ calculations for container plants. Correlating water use to the area covered by the canopy would be an alternative approach to calculating $\mathrm{K}_{\mathrm{c}}$, independent of container surface area and plant spacing, as $K_{c}$ values are known to vary with different container spacing (Burger et al., 1987; Regan, 1994).

$\mathrm{K}_{\mathrm{c}}$ values for some species varied occasionally between consecutive days. Smaller differences seem to be associated with the summer months when water use was high, but in some cases $\mathbf{K}_{\mathbf{c}}$ varied during fall and winter by one to two units for consecutive sampling days. These discrepancies indicate that plant water use of species in this experiment may not respond in the same manner as the reference crop to changes in environmental conditions. Annandale and Stockle (1990) investigated the stability of full-canopy cover crop coefficients and found that environmental factors did not affect ET in the same way they affected the crop of interest.

In Davis, Photinia $\mathrm{K}_{\mathrm{ccim}}$ was 1.8 and 2.7 on 27 and 28 Oct., and $\mathrm{K}_{\mathrm{c}_{\text {atm }}}$ was 2.7 and 2.3, respectively. The low $\mathrm{K}_{\mathrm{c} \text { cim }}$ on $27 \mathrm{Oct}$. was due to the high $\mathrm{ET}_{\text {cim }}$ of $0.8 \mathrm{~cm}$ versus the $\mathrm{ET}_{\mathrm{atm}}$ of $0.5 \mathrm{~cm}$. Upon examination of the climatic components that enter the $\mathrm{ET}_{\text {cim }}$ equation, we found that higher wind speed was the major difference between the 2 days, while solar radiation and temperature were similar. Wind speed has a profound effect upon $\mathrm{ET}_{\text {cim }}$, but the closed canopy structure of our container plants may have prevented increased water use proportional to the wind speed. Also, plants may have closed their stomates in response to high wind speed during the day to prevent desiccation. Sensitivity analysis of $K_{c}$ values under different environmental conditions found that at very low wind speeds, $K_{c}$ increased sharply because the reference crop had lower heat exchange (Annandale and Stockle, 1990). At higher wind speeds, $K_{c}$ either increased or decreased, depending on stomatal resistance of the crop. Wind speed increases with elevation above ground surface (Rosenberg et al., 1983), and discrepancies between $\mathrm{ET}_{\text {cim }}$ and $\mathrm{ET}_{\text {atm }}$ may result from CIMIS stations' measuring wind speed at $2 \mathrm{~m}$ above ground, while atmometers in our experiment were placed at canopy height, $\approx 50$ $\mathrm{cm}$ above ground. Therefore, $\mathrm{ET}_{\mathrm{cim}}$ may not provide an accurate reference ET for container crops on windy days.

$\mathrm{ET}_{\text {cim }}$ and $\mathrm{ET}_{\text {atm }}$ at each study site were compared by calculating a regression with $\mathrm{ET}_{\mathrm{cim}}$ as the dependent variable for both study locations. For Riverside, $\mathrm{ET}_{\text {cim }}=0.974 \times \mathrm{ET}_{\text {atm }}\left(R^{2}=0.96\right)$, and for Davis $\mathrm{ET}_{\mathrm{cim}}=1.13 \times \mathrm{ET}_{\mathrm{atm}}\left(R^{2}=0.95\right)$. The CIMIS station

Table 1. Results of the general linear procedure calculated for water use, $\mathrm{Kc}_{\mathrm{ctm}}$ and $\mathrm{Kc}_{\mathrm{cim}}$ of 12 species of woody ornamental plants growing in containers at Riverside and Davis, Calif., and sampled for water use (milligrams per day per plant) over a 20-month period.

\begin{tabular}{|c|c|c|c|c|c|c|c|}
\hline \multirow{2}{*}{$\begin{array}{l}\text { Source of } \\
\text { variation }\end{array}$} & \multirow[b]{2}{*}{ df } & \multicolumn{2}{|c|}{ Water use } & \multicolumn{2}{|c|}{$\mathrm{K}_{\mathrm{atm}}$} & \multicolumn{2}{|c|}{$\mathrm{Kc}_{\mathrm{cim}}$} \\
\hline & & Mean square & F value & Mean square & F value & Mean square & F value \\
\hline$\overline{\text { Species }(S)^{\mathrm{z}}}$ & 11 & 331,862 & $13.4^{* * *}$ & 33.6 & $29.2^{* * *}$ & 21.4 & $22.5^{\text {*.F." }}$ \\
\hline Location (L) & 1 & 256,932 & $18.7^{* * *}$ & 539.0 & $1096.1^{* * *}$ & 164.9 & $545.4^{* * * *}$ \\
\hline $\mathrm{S} \times \mathrm{L}$ & 11 & 146,937 & $10.7^{* * *}$ & 8.3 & $16.9^{* * *}$ & 5.5 & $18.4^{* * *}$ \\
\hline Month (M) & 9 & $7,148,360$ & $521.7^{* * *}$ & 99.1 & $201.6^{* * *}$ & 39.4 & $130.2^{* * *}$ \\
\hline $\mathbf{S} \times \mathbf{M}$ & 99 & 49,566 & $3.6^{* * *}$ & 2.7 & $5.5^{* * *}$ & 1.5 & $5.1^{* * * *}$ \\
\hline $\mathbf{L} \times \mathbf{M}$ & 5 & 569,707 & $41.6^{* * *}$ & 0.8 & $1.6^{\mathrm{NS}}$ & 11.9 & $39.5^{* * *}$ \\
\hline $\mathrm{S} \times \mathrm{M} \times \mathrm{L}$ & 50 & 40,436 & $2.9^{* * *}$ & 1.6 & $3.3^{* * * *}$ & 1.2 & $4.0^{* * *}$ \\
\hline
\end{tabular}

Test of hypotheses used the block $\times$ species interaction for species.

ns, ${ }^{* * *}$ Nonsignificant or significant at $P<0.0001$. 
Raphiolepis
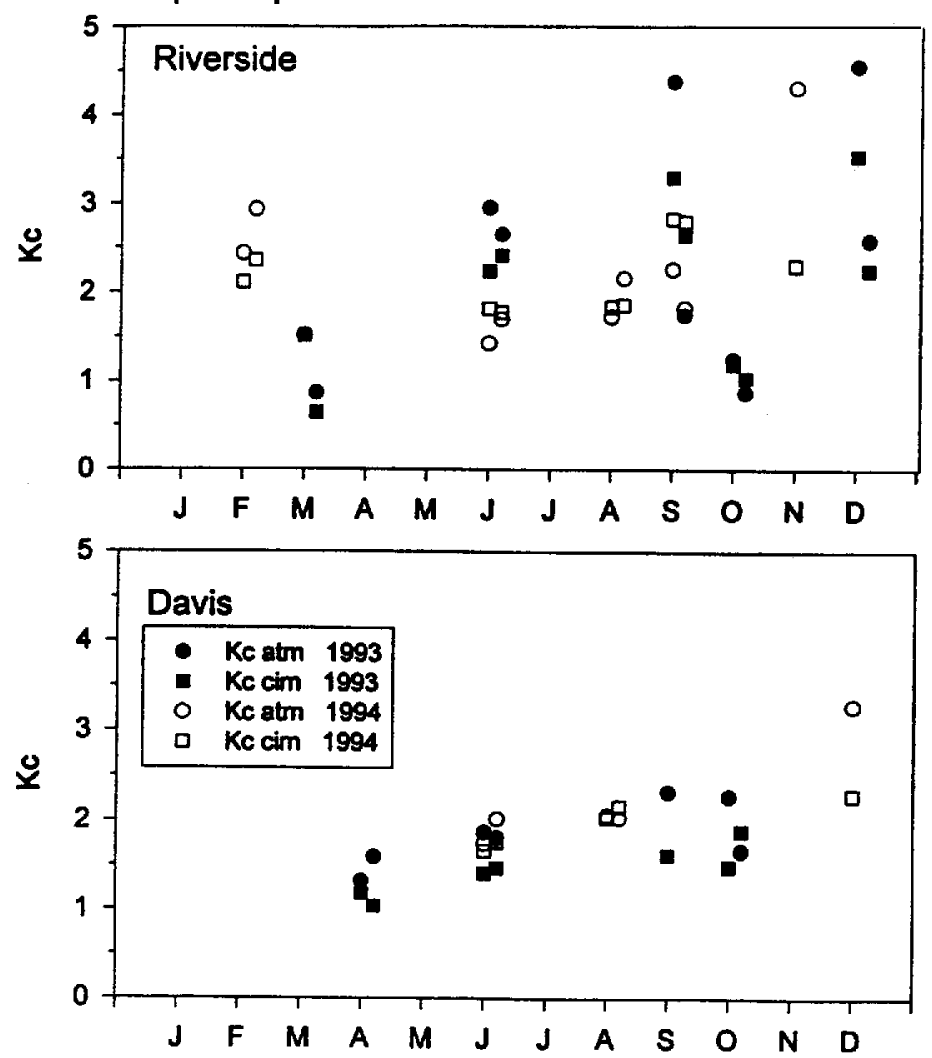

Juniper
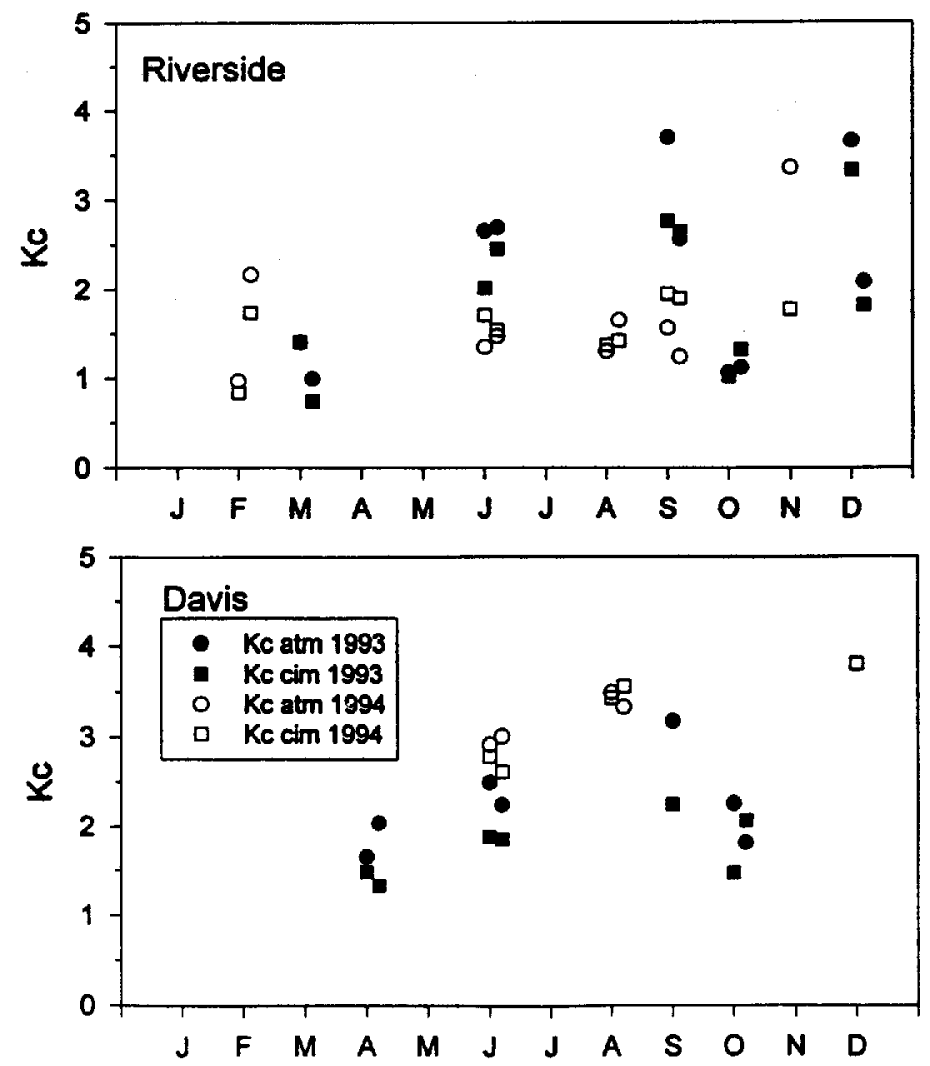

Pittosporum
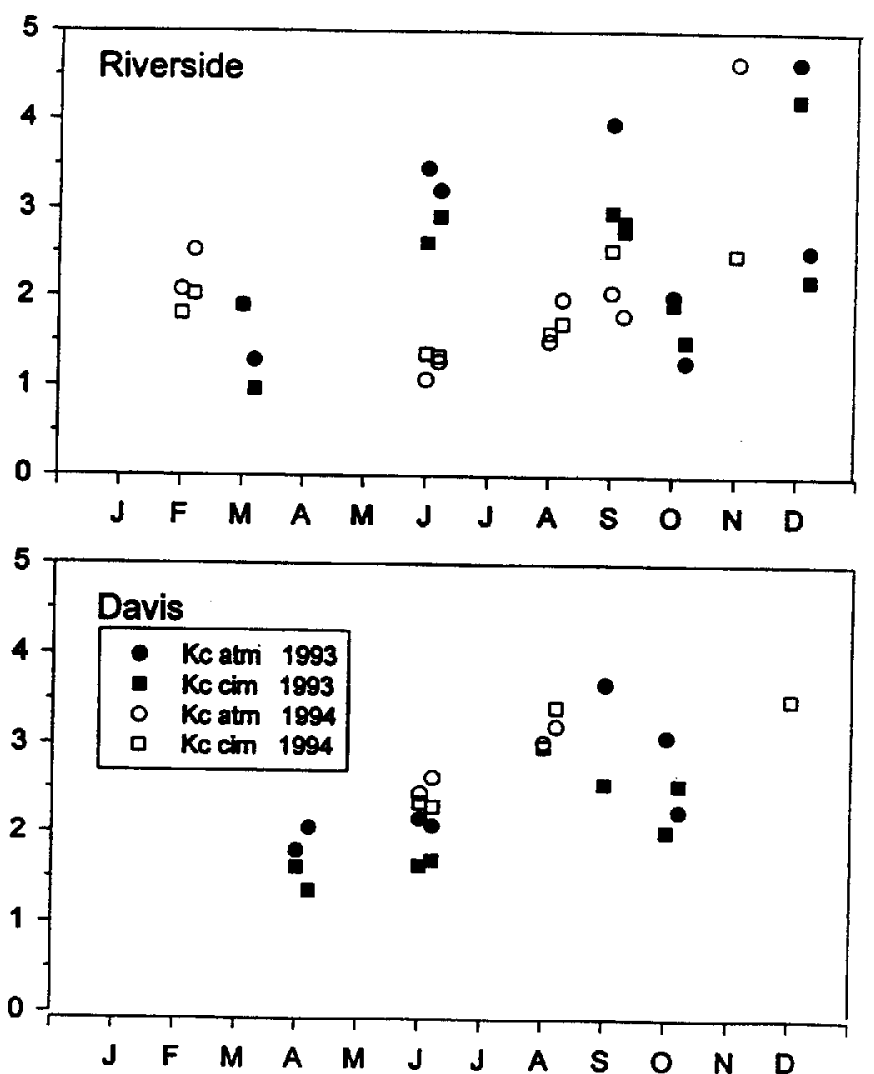

Photinia
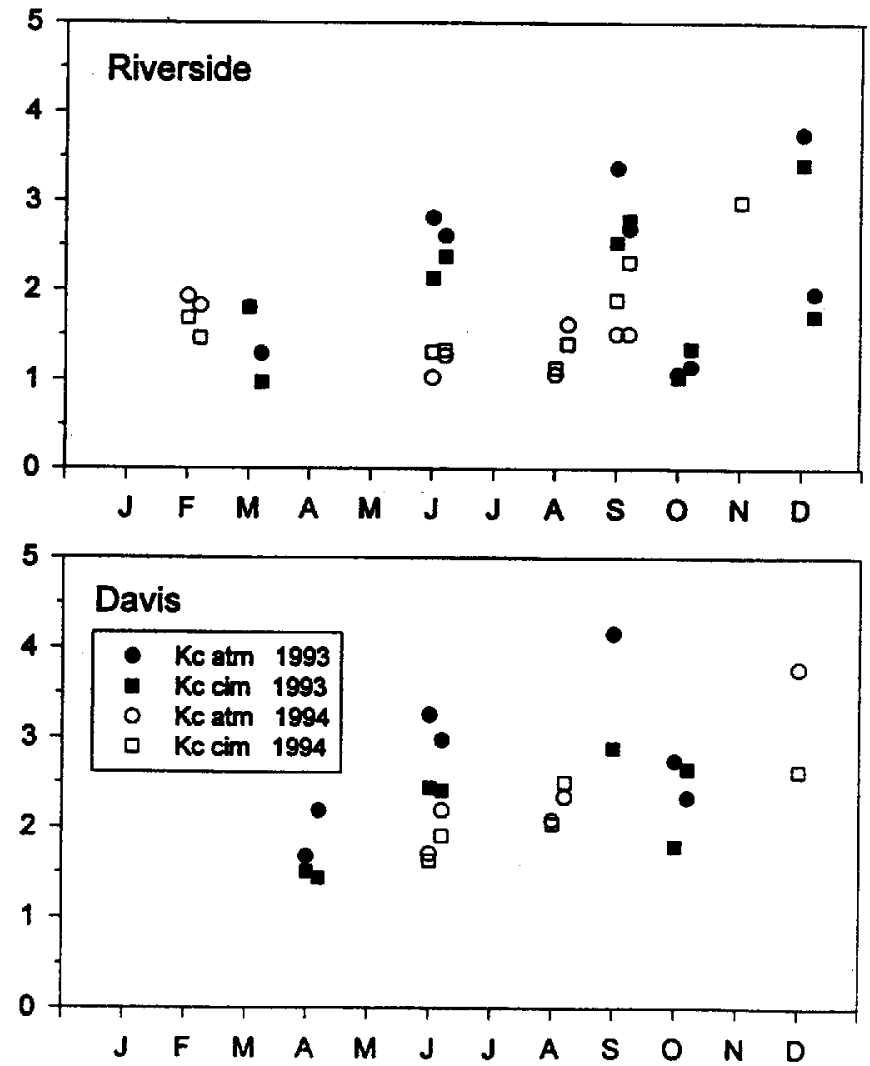

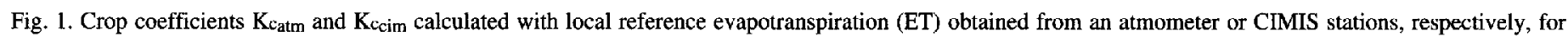

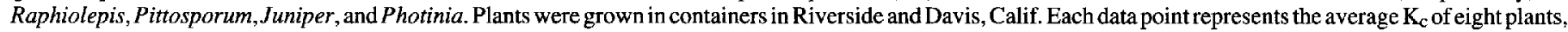
the two points per month represent $K_{c}$ values determined on 2 consecutive days. 


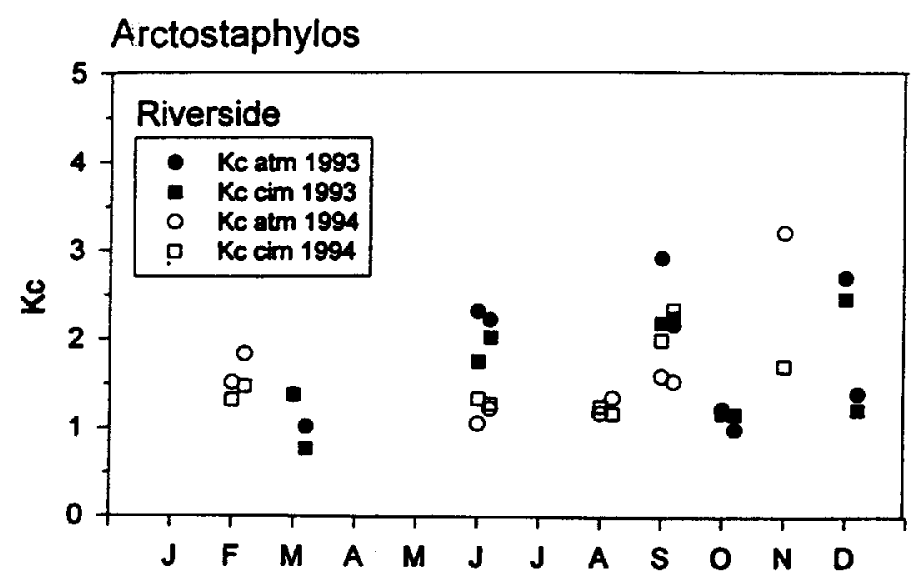

\section{Heteromeles}
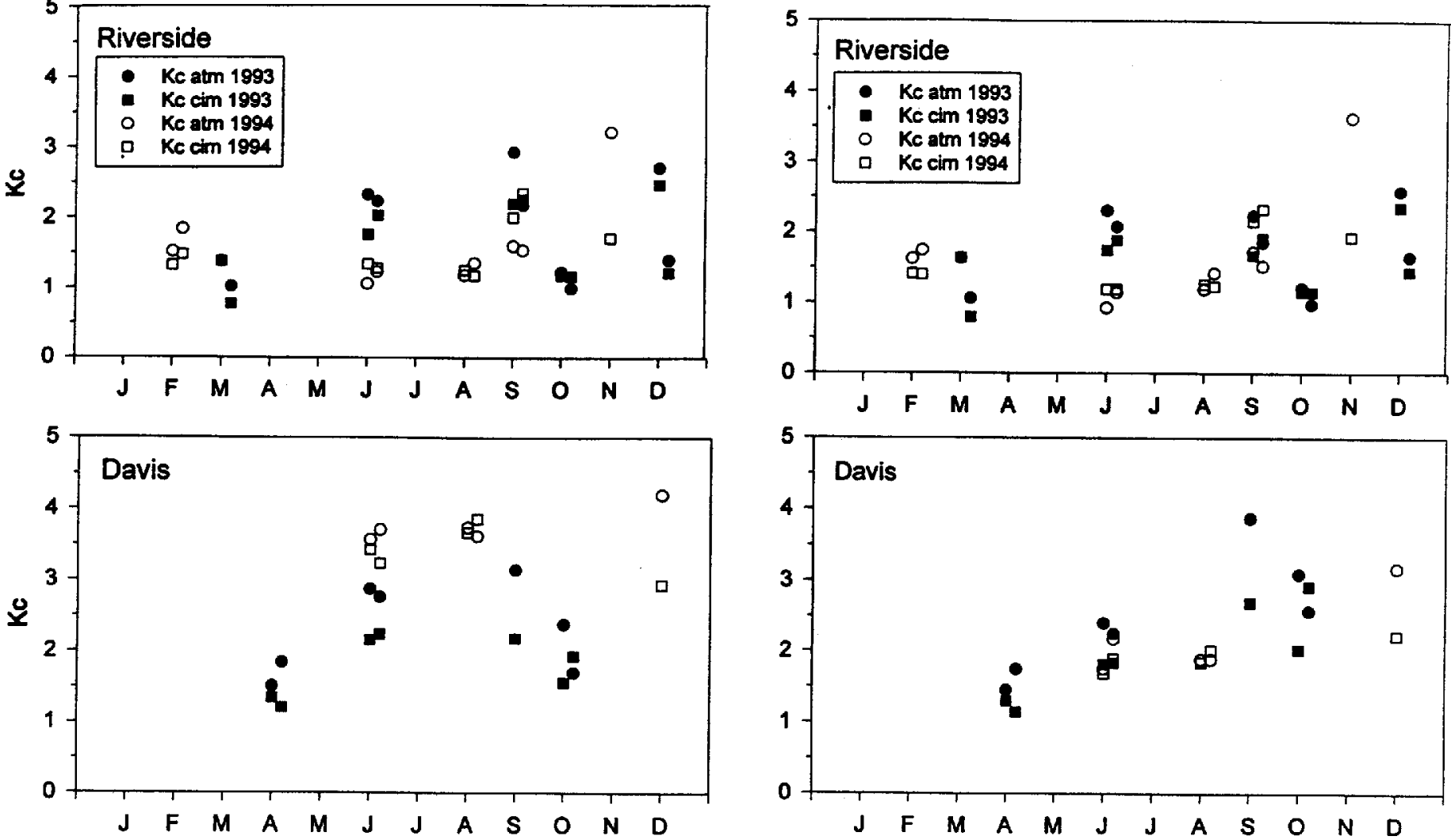

Buxus
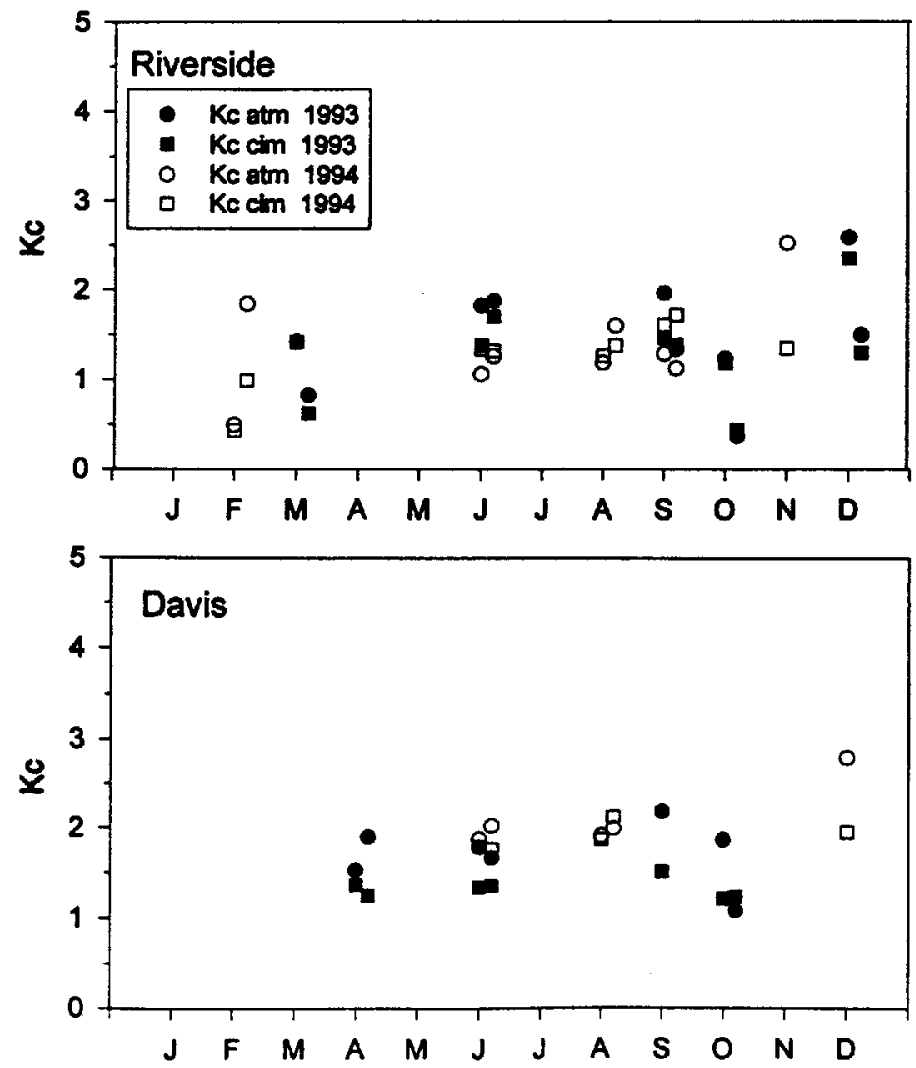

Ceanothus
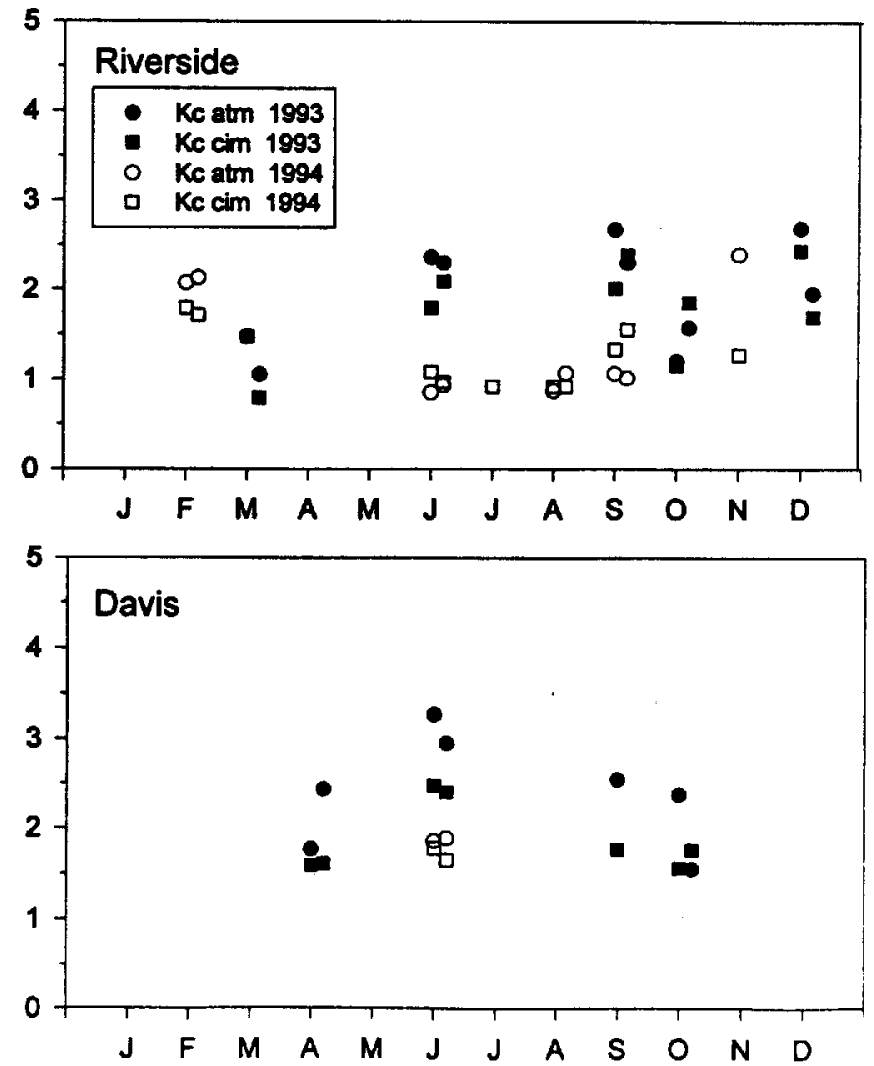

Fig. 2. Crop coefficients $\mathrm{K}_{\mathbf{c}_{\mathrm{atm}}}$ and $\mathrm{K}_{\mathbf{c}_{\mathrm{cim}}}$ calculated with local reference evapotranspiration (ET) obtained from an atmometer or CIMIS stations, respectively, for Arctostaphylos, Heteromeles, Buxus, and Ceanothus. Plants were grown in containers in Riverside and Davis, Calif. Each data point represents the average $\mathrm{K}_{\mathrm{c}}$ of eight plants, the two points per month represent $\mathrm{K}_{\mathrm{c}}$ values determined on 2 consecutive days. 
Rhamnus
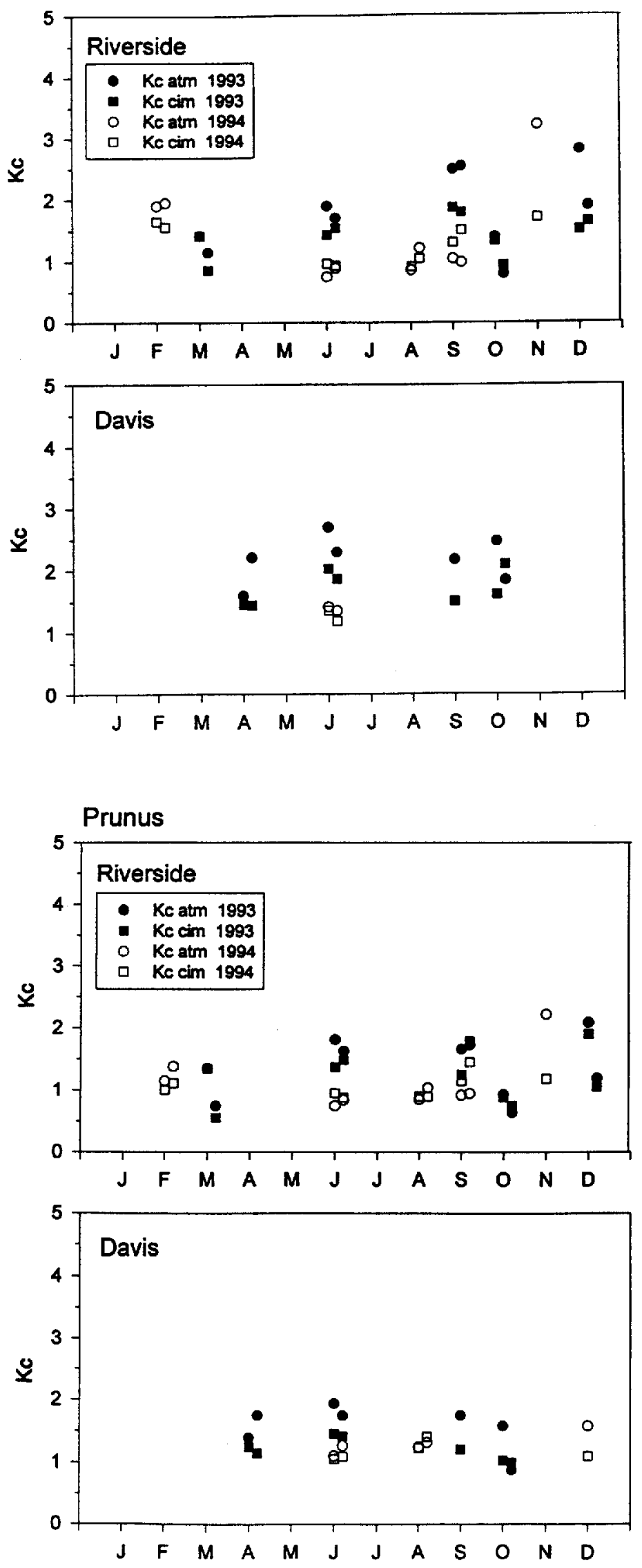

Cercis
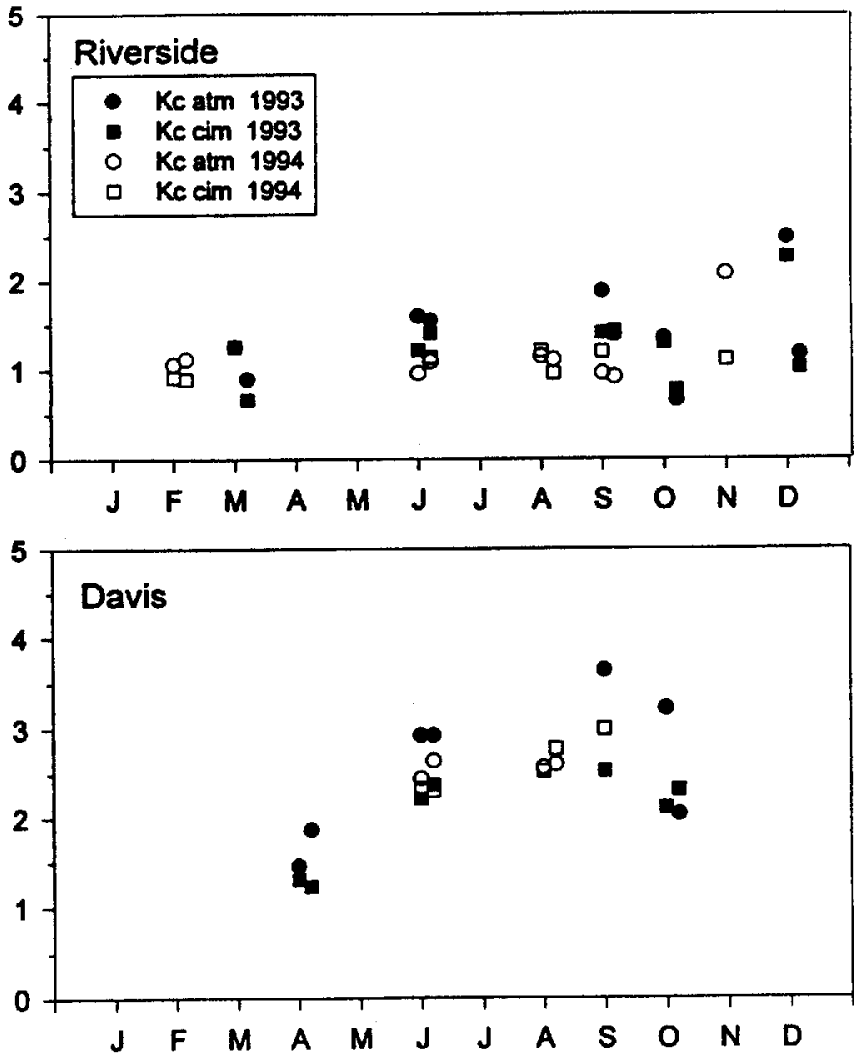

\section{Cercocarpus}
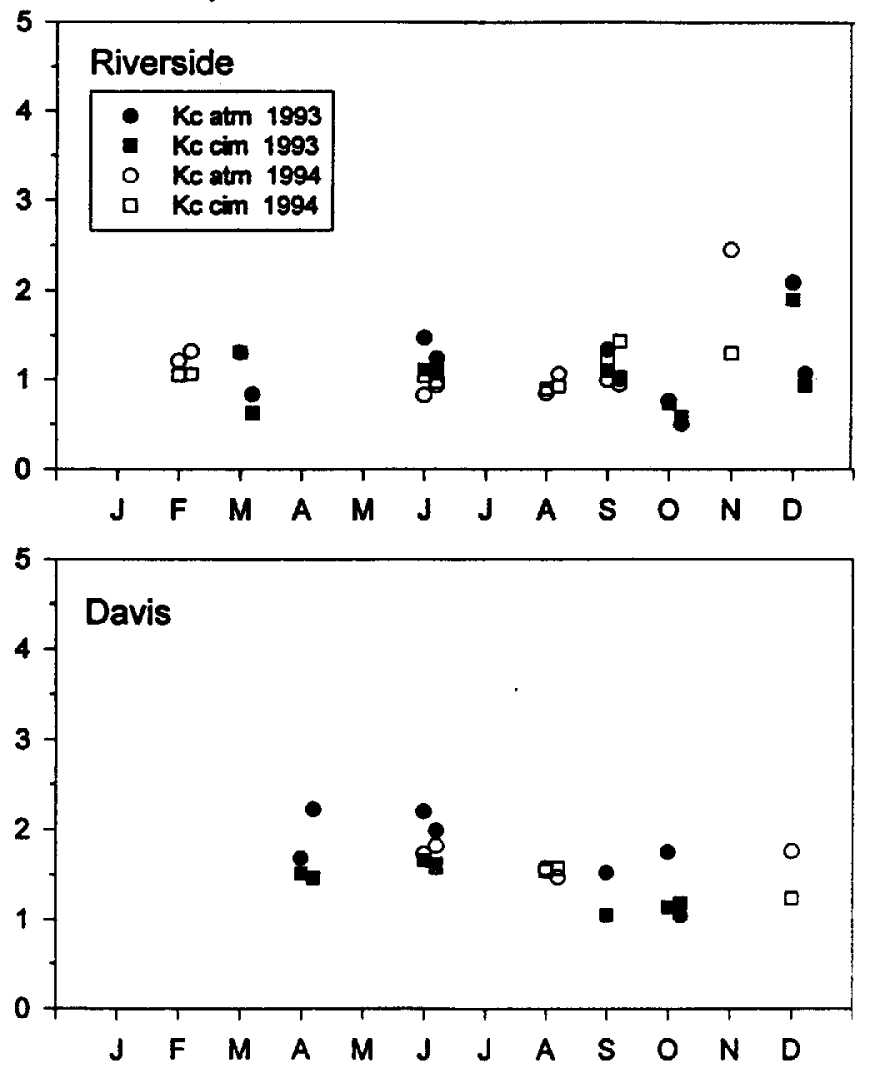

Fig. 3. Crop coefficients $\mathrm{K}_{\mathrm{c}_{\mathrm{atm}}}$ and $\mathrm{K}_{\mathrm{ccim}}$ calculated with local reference evapotranspiration (ET) obtained from an atmometer or CIMIS stations, respectively, for Rhamnus, Cercis, Prunus, and Cercocarpus. Plants were grown in containers in Riverside and Davis, Calif. Each data point represents the average $\mathrm{K}_{\mathrm{c}}$ of eight plants, the two points per month represent $K_{\mathrm{c}}$ values determined on 2 consecutive days. 
Table 2. Twenty-month average water use, $K_{c_{a t m}}$, and $K_{c_{c i m}}$ of 12 woody ornamental species grown in containers at Davis $(n=1152)$ and Riverside $(\mathrm{n}=1920)$, Calif

\begin{tabular}{|c|c|c|c|c|c|c|c|}
\hline \multirow[b]{2}{*}{ Species } & \multicolumn{3}{|c|}{ Davis } & \multirow[b]{2}{*}{ Species } & \multicolumn{3}{|c|}{ Riverside } \\
\hline & $\begin{array}{c}\text { Plant water use } \\
\left(\mathrm{mg} \cdot \mathrm{d}^{-1}\right)\end{array}$ & $\mathrm{K}_{\mathrm{arm}}$ & $\mathbf{K}_{\mathbf{c}_{\text {cim }}}$ & & $\begin{array}{l}\text { Plant water use } \\
\left(\mathrm{mg} \cdot \mathrm{d}^{-1}\right)\end{array}$ & $\mathrm{K}_{\mathrm{c}_{\mathrm{atm}}}$ & $\mathrm{Kc}_{\mathrm{cim}}$ \\
\hline Arctostaphylos & $405 \mathrm{a}^{\mathrm{z}}$ & $2.9 \mathrm{a}$ & $2.5 \mathrm{a}$ & Raphiolepis & $331 \mathrm{a}$ & $2.3 \mathrm{a}$ & $2.1 \mathrm{a}$ \\
\hline Juniperus & $363 b$ & $2.8 \mathrm{ab}$ & $2.4 \mathrm{a}$ & Pittosporum & $320 \mathrm{a}$ & $2.3 \mathrm{a}$ & $2.1 \mathrm{a}$ \\
\hline Cercis & $350 \mathrm{~b}$ & $2.6 \mathrm{c}$ & $2.2 \mathrm{bc}$ & Juniperus & $270 \mathrm{~b}$ & $1.9 \mathrm{~b}$ & $1.7 \mathrm{~b}$ \\
\hline Pittosporum & $344 b$ & $2.8 \mathrm{ab}$ & $2.3 \mathrm{ab}$ & Photinia & $264 b$ & $2.0 \mathrm{~b}$ & $1.8 \mathrm{~b}$ \\
\hline Photinia & $301 \mathrm{c}$ & $2.6 \mathrm{bc}$ & $2.1 \mathrm{c}$ & Arctostaphylos & $242 \mathrm{bc}$ & $1.6 \mathrm{c}$ & $1.5 \mathrm{c}$ \\
\hline Heteromeles & $272 \mathrm{~cd}$ & $2.4 \mathrm{~d}$ & $1.9 \mathrm{~d}$ & Heteromeles & $241 \mathrm{bcd}$ & $1.6 \mathrm{c}$ & $1.5 \mathrm{c}$ \\
\hline Raphiolepis & $243 \mathrm{de}$ & $2.0 \mathrm{e}$ & $1.7 \mathrm{e}$ & Buxus & $218 \mathrm{cde}$ & $1.3 \mathrm{de}$ & $1.2 \mathrm{de}$ \\
\hline Buxus & $237 \mathrm{de}$ & $1.9 \mathrm{ef}$ & $1.6 \mathrm{ef}$ & Ceanothus & $206 \mathrm{def}$ & $1.6 \mathrm{c}$ & $1.5 \mathrm{c}$ \\
\hline Ceanothus & $236 \mathrm{de}$ & $2.3 \mathrm{~d}$ & $1.9 \mathrm{~d}$ & Rhamnus & 199 efg & $1.5 \mathrm{~cd}$ & $1.4 \mathrm{~cd}$ \\
\hline Cercocarpus & $216 \mathrm{e}$ & $1.7 \mathrm{f}$ & $1.4 \mathrm{f}$ & Cercis & 184 efg & $1.2 \mathrm{e}$ & $1.2 \mathrm{ef}$ \\
\hline Rhamnus & 202 ef & $2.1 \mathrm{e}$ & $1.7 \mathrm{e}$ & Prunus & $173 \mathrm{fg}$ & $1.2 \mathrm{e}$ & $1.1 \mathrm{ef}$ \\
\hline Prunus & $174 \mathrm{f}$ & $1.5 \mathrm{~g}$ & $1.2 \mathrm{~g}$ & Cercocarpus & $167 \mathrm{~g}$ & $1.1 \mathrm{e}$ & $1.0 \mathrm{f}$ \\
\hline
\end{tabular}

${ }^{\mathrm{z}}$ Mean separation within each column by Fisher's protected LSD $(P<0.05)$.

in Riverside was located $\approx 100 \mathrm{~m}$ from the nursery study site. The distance between the Davis CIMIS station and the nursery study site was $\approx 2 \mathrm{~km}$. Higher wind speeds at the Davis CIMIS location (Fig. 4) compared to the more protected nursery site at Davis could account for $\mathrm{K}_{\mathrm{c}_{a t m}}$ underpredicting $\mathrm{K}_{\mathrm{c}_{\mathrm{cim}}}$ by $13 \%$. Microclimate has a strong influence on water use and can change considerably over a short distance (Oke, 1978). The difference between $\mathrm{ET}_{\mathrm{atm}}$ and $\mathrm{ET}_{\mathrm{cim}}$ over the short distance in Davis suggests that an appropriately placed atmometer provides ET information that is specific to the nursery microclimate and more accurate for use in a $\mathrm{K}_{\mathbf{c}}$ calculation.

Differences between $\mathrm{ET}_{\mathrm{atm}}$ and ETcim introduced considerable variability to $K_{c_{a t m}}$ and $K_{c_{c i m}}$ on the same day. When water use is low during the winter months, small differences in reference ET resulted in large differences in $\mathrm{K}_{\mathrm{c}}$. Large discrepancies between $\mathrm{K}_{\mathrm{c}_{\mathrm{atm}}}$ and $\mathrm{K}_{\mathrm{cim}}$, up to $90 \%$, were found in November 1994. Although the difference in $\mathrm{ET}_{\text {cim }}$ and $\mathrm{ET}_{\text {atm }}$ was only $47 \%$ at that time, far greater differences between the two ET values at times when plant water use was high resulted in much smaller differences between $K_{c}$ values. It seems, therefore, that $\mathrm{K}_{c}$ during the winter or during times when water use is low is less reliable than during the summer, when water use is usually high, and small discrepancies in reference ET will result

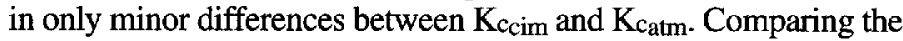
ranking of water use and the two $K_{c}$ values in Table 3 confirms that $\mathrm{K}_{\mathrm{c}}$ tends to be artificially high in winter and is not correlated to the low water use during that time.

In this study we demonstrated that $\mathrm{K}_{\mathrm{c}}$ varied for each species by growing location and time of year. In contrast, Burger et al. (1987) reported that $\mathrm{K}_{\mathrm{c}}$ values of three species of containerized ornamentals remained fairly constant at four different locations in California. Similar $K_{c}$ values in that study can probably be attributed to uniform plant material and to data that were collected only in summer during high water use. In our study, differences in plant growth developed over the 2-year period, with some species performing better in one location versus the other. Growth rates also likely differed between the two locations for individual species. Stage of crop development and growth rate affected $\mathrm{K}_{\mathrm{c}}$ values of containerized woody plants (Regan, 1994).

It is questionable that $K_{c}$ is a useful concept for container crops in general, because it was developed for specific conditions that are not met by container plants. Annandale and Stockle (1990) state

Table 3. Average monthly water use, $\mathrm{K}_{\mathrm{c}_{\mathrm{atm}}}$, and $\mathrm{K}_{\mathrm{c}_{\mathrm{cim}}}$ of 12 woody ornamental species grown in containers at Davis and Riverside, Calif. ( $\mathrm{n}=192$ ).

\begin{tabular}{|c|c|c|c|c|c|c|c|}
\hline \multirow[b]{2}{*}{ Month } & \multicolumn{3}{|c|}{ Davis } & \multirow[b]{2}{*}{ Month } & \multicolumn{3}{|c|}{ Riverside } \\
\hline & $\begin{array}{c}\text { Plant water use } \\
\left(\mathrm{mg} \cdot \mathrm{d}^{-1}\right)\end{array}$ & $\mathbf{K}_{\mathfrak{c}_{\text {cim }}}$ & $\mathrm{K}_{\mathbf{c}_{\mathrm{atm}}}$ & & $\begin{array}{l}\text { Plant water use } \\
\left(\mathrm{mg} \cdot \mathrm{d}^{-\mathrm{t}}\right)\end{array}$ & $\mathrm{K}_{\mathrm{c}_{\mathrm{cim}}}$ & $K_{c_{a t m}}$ \\
\hline & & & & 1993 & & & \\
\hline March & --- & --- & --- & March & $112 \mathrm{fg}^{\mathrm{z}}$ & $1.49 \mathrm{c}$ & $1.49 \mathrm{~d}$ \\
\hline April & $98 \mathrm{e}$ & $1.36 \mathrm{~d}$ & $1.77 \mathrm{e}$ & April & $41 \mathrm{~h}$ & $0.54 \mathrm{e}$ & $0.61 \mathrm{~g}$ \\
\hline June & $282 \mathrm{c}$ & $1.88 \mathrm{bc}$ & $2.40 \mathrm{c}$ & June & --- & --- & $\ldots$ \\
\hline July & $\cdots$ & $\cdots$ & --- & July & $231 \mathrm{~d}$ & $1.85 \mathrm{~b}$ & $2.23 \mathrm{~b}$ \\
\hline September & $161 \mathrm{~d}$ & $1.97 \mathrm{~b}$ & $2.85 \mathrm{~b}$ & September & $133 \mathrm{f}$ & $2.06 \mathrm{a}$ & $2.36 \mathrm{~b}$ \\
\hline October & $173 \mathrm{~d}$ & $1.78 \mathrm{c}$ & $2.08 \mathrm{~d}$ & October & $115 \mathrm{fg}$ & $1.12 \mathrm{~d}$ & $1.07 \mathrm{f}$ \\
\hline December & $-\cdots$ & -- & --- & $\begin{array}{l}\text { December } \\
1994\end{array}$ & $124 \mathrm{f}$ & $2.15 \mathrm{a}$ & $2.40 \mathrm{~b}$ \\
\hline February & -- & --- & --- & February & $96 \mathrm{~g}$ & $1.40 \mathrm{c}$ & $1.69 \mathrm{c}$ \\
\hline June & $535 a$ & $1.99 \mathrm{~b}$ & $2.18 \mathrm{~cd}$ & June & $490 \mathrm{~b}$ & $1.25 \mathrm{~d}$ & $1.08 \mathrm{f}$ \\
\hline August & $495 \mathrm{~b}$ & $2.43 \mathrm{a}$ & $2.37 \mathrm{c}$ & August & 517 a & $1.23 \mathrm{~d}$ & $1.29 \mathrm{e}$ \\
\hline September & --- & -- & --- & September & $455 \mathrm{c}$ & $1.86 \mathrm{~b}$ & $1.34 \mathrm{de}$ \\
\hline November & -- & --- & --- & November & $190 \mathrm{e}$ & $1.77 \mathrm{~b}$ & $3.33 \mathrm{a}$ \\
\hline December & $125 \mathrm{e}$ & $2.40 \mathrm{a}$ & $3.43 \mathrm{a}$ & December & --- & --- & --- \\
\hline
\end{tabular}

${ }^{\mathrm{X}}$ Mean separation within each column by Fisher's protected LSD $(\mathrm{P}<0.05)$. 

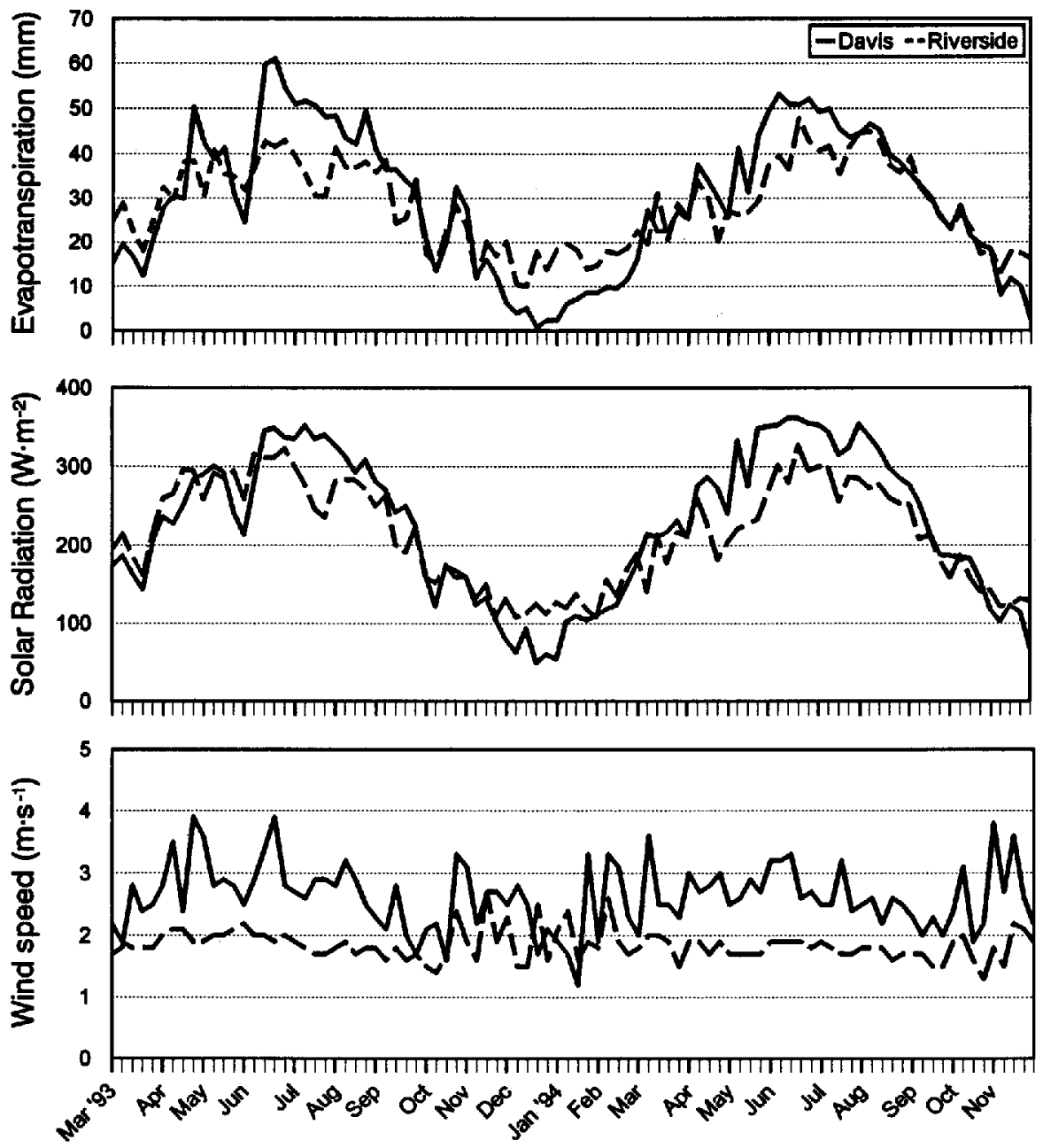

increased from spring to fall in Davis, probably because of differences in growth rates. $\mathrm{K}_{\mathrm{c}}$ values of the high water users fluctuated considerably and seem to be more specific to a growth stage or time of year and growing location. Therefore, general $\mathrm{K}_{\mathrm{c}}$ values have limited value for plants with high water demand and need to be developed for individual growth stages and microclimates for these plants. $K_{\mathfrak{c}}$ values of high water users, as determined in this study, are not useful for irrigation scheduling. However, the stable ranking of relative water use of the 12 species in each location provides useful information for grouping plants with similar water needs. Atmometers placed adjacent to the plants provided a reliable and economical estimate of ET and might be used to determine reference ET in this situation.

\section{Literature Cited}

Allen, R.G. 1993. New approaches to estimating crop cvapotranspiration. Acta Hort. 335:287-294.

Annandale, J.G. and G.O. Stockle. 1990. Sensitivity analysis of evapotranspiration crop coefficients fluctuation with climate. Trans. ASAE 90-2645.

Baker, K.F. 1985. The UC System for producing healthy container-grown plants. Surrey Beatty \& Sons, Chipping Norton, Australia.

Blaney H.F. and W.D. Criddle. 1950. Determining water requirements in irrigated areas from climatological and irrigation data. USDA(SCS)TP-96.

Burger, D.W., J.S. Hartin, D.R. Hodel, T.A. Lukaszewski, S.A. Tjosvold, and S.A. Wagner. 1987. Water use in California's ornamental nurseries. Calif. Agr. Sept./Oct.:7-8. Doorenbos, J. and W.O. Pruitt. 1975. Guidelines for predicting crop water requirements. FAO Irr. Drainage Paper 24.

Doorenbos, J. 1976. Agro-meteorological field stations. FAO Irr. Drainage Paper 27.

Fig. 4. Cumulative weekly evapotranspiration, and average weekly solar radiation and wind speed obtained from CIMIS stations in Davis and Riverside, Calif.

Little, T.M. and F.J. Hills. 1978. Agricultural experimentation. Wiley, New York. p. 220-227.

Makkink, G.F. 1957. Testing the Penman formula by means of lysimeters. J. Inst. Water Eng. 11:277-288.

Oke, T.R. 1978. Boundary layer climates. Methuen \& Co., London.

Penman, H.L. 1948. Natural evapotranspiration from open water, bare soil and grass. Proc. Royal Soc. London Ser. A. 193:120-145.

Regan, R.P. 1994. Variation in water use of container-grown plants. Comb. Proc. Intl. Plant Prop. Soc. 44:310-312.

Rosenberg, N.J., B.L. Blad, and S.B. Verma. 1983. Microclimate: The biological environment. Wiley, New York.

Snyder, R.L., B.J. Lanini, D.A. Shaw, and W.O. Pruitt. 1987. Using reference evapotranspiration $\left(E T_{o}\right)$ and crop coefficients to estimate crop evapotranspiration $\left(E T_{c}\right)$ for agronomic crops, grasses and vegetable crops. Univ. of Calif. Coop. Ext. Lftt. 21427.

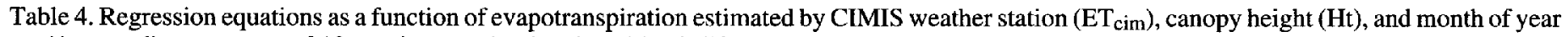
$(t)$ to predict water use of 12 species growing in Riverside, Calif.

\begin{tabular}{|c|c|c|}
\hline Species & Equation & \\
\hline Arctostaphylos & $-1293+2.3 \mathrm{Ht}+3454 \mathrm{ET}_{\operatorname{cim}}-599 \cos (\mathrm{t})+2007 \mathrm{ET}_{\operatorname{cim}} \times \cos (\mathrm{t})$ & $\left(R^{2}=0.86\right)$ \\
\hline Buxus & $-643+0.06 \mathrm{Ht}^{2}+1769 \mathrm{ET}_{\text {cim }}+3.6 \mathrm{Ht} \times \cos (\mathrm{t})$ & $\left(R^{2}=0.94\right)$ \\
\hline Ceanothus & $117+1175 \sin (\mathrm{t})-3051 \mathrm{ET}_{\mathrm{cim}} \times \sin (\mathrm{t})+301 \mathrm{ET}_{\operatorname{cim}} \times \cos (\mathrm{t})$ & $\left(R^{2}=0.90\right)$ \\
\hline Cercis & $-841+2386 \mathrm{ET}_{\operatorname{cim}}-234 \cos (\mathrm{t})+E \mathbf{T}_{\operatorname{cim}} \times \cos (\mathrm{t})$ & $\left(R^{2}=0.94\right)$ \\
\hline Cercocarpus & $-828+2345 \mathrm{ET}_{\mathrm{cim}}-329 \cos (\mathrm{t})+1137 \mathrm{ET}_{\mathrm{cim}} \times \cos (\mathrm{t})$ & $\left(R^{2}=0.87\right)$ \\
\hline Heteromeles & $-1275+3603 \mathrm{ET}_{\mathrm{cim}}-615 \cos (\mathrm{t})+\mathrm{ET}_{\mathrm{cim}} \times \cos (\mathrm{t})$ & $\left(R^{2}=0.76\right)$ \\
\hline Juniperus & $-713+2202 \mathrm{ET}_{\mathrm{cim}}-131 \mathrm{ET}_{\mathrm{cim}} \times \sin (\mathrm{t})+331 \mathrm{ET}_{\mathrm{cim}} \times \cos (\mathrm{t})$ & $\left(R^{2}=0.87\right)$ \\
\hline Photinia & $-1263+3610 \mathrm{ET}_{\operatorname{cim}}-555 \cos (\mathrm{t})+1947 \mathrm{ET}_{\mathrm{cim}} \times \cos (\mathrm{t})$ & $\left(R^{2}=0.90\right)$ \\
\hline Pittosporum & $-1227+0.26 \mathrm{Ht}^{2}+3293 \mathrm{ET}_{\mathrm{cim}}-658 \cos (\mathrm{t})+2107 \mathrm{ET}_{\mathrm{cim}} \times \cos (\mathrm{t})$ & $\left(R^{2}=0.88\right)$ \\
\hline Prunus & $-838+2388 \mathrm{ET}_{\operatorname{cim}}-383 \cos (\mathrm{t})+1308 \mathrm{ET}_{\mathrm{cim}} \times \cos (\mathrm{t})$ & $\left(R^{2}=0.84\right)$ \\
\hline Raphiolepis & $-1575+5.3 \mathrm{Ht}+4004 \mathrm{ET}_{\mathrm{cim}}-722 \cos (\mathrm{t})+2277 \mathrm{ET}_{\mathrm{cim}} \times \cos (\mathrm{t})$ & $\left(R^{2}=0.87\right)$ \\
\hline Rhamnus & $-802+0.05 \mathrm{Ht}^{2}+2184 \mathrm{ET}_{\operatorname{cim}}-332 \cos (\mathrm{t})+1127 \mathrm{ET}_{\operatorname{cim}} \times \cos (\mathrm{t})$ & $\left(R^{2}=0.87\right)$ \\
\hline
\end{tabular}

